\title{
HUBUNGAN KEPRIBADIAN DAN AVOIDANCE PROCRASTINATION PADA MAHASISWA
}

\section{The Relationship of Personality and Avoidance Procrastination Among University Students}

\author{
Thoyyibatus Sarirah ${ }^{1)}$, Yeni Puji Rahayu ${ }^{2)}$ \\ 1)2)Fakultas IImu Sosial dan IImu Politik, Universitas Brawijaya
}

Diterima 20 Agustus 2018

\begin{abstract}
This study aimed to know the relationship between the personality and avoidance procrastination of university student. This study used a quantitative correlation with a sample of 400 students obtained by using accidental sampling. This study used two scales that is Big Five Inventory (BFI) by McCrae \& Costa (1997) to measure personality and Adult Inventory Procrastination (AIP) by McCown \& Johnson (1989) to measure avoidance procrastination. Data analysis used correlation technique of pearson product moment. The results of this study showed that extraversion, agreeableness and conscientiousness had relationship with avoidance procrastination, but neuroticism and openness to new experience did not have relationship with avoidance procrastination
\end{abstract}

Keywords: Avoidance Procrastination, Personality, University Students

ABSTRAK
Penelitian ini dilakukan untuk mengetahui hubungan antara kepribadian dengan avoidance procrastination pada mahasiswa. Pendekatan penelitian yang digunakan adalah kuantitatif dengan jenis penelitian korelasional. Sampel penelitian adalah 400 mahasiswa yang diperoleh dengan menggunakan jenis accidental sampling. Penelitian ini menggunakan dua skala, yaitu: Big Five Inventory (BFI) oleh McCrae \& Costa (1997) untuk mengukur kepribadian dan Adult Inventory Procrastination (AIP) oleh McCown \& Johnson (1989) untuk mengukur avoidance procrastination. Analisis data menggunakan teknik statistik korelasi Pearson product moment. Hasil penelitian menunjukkan bahwa extraversion, agreeableness dan conscientiousness memiliki hubungan dengan avoidance procrastination, sedangkan neuroticism dan openness to new experience tidak memiliki hubungan dengan avoidance procrastination. Kata Kunci: Avoidance Procrastination, Kepribadian, Mahasiswa

\section{PENDAHULUAN}

Mahasiswa didefinisikan sebagai individu yang sedang menimba ilmu ditingkat universitas, lembaga atau akademi yang sederajat, baik negeri maupun swasta (Siswoyo, 2007). Mahasiswa mempunyai banyak aktivitas baik aktivitas yang berhubungan dengan akademik maupun non akademik.

\footnotetext{
*Korespondensi Penulis:

E-mail: thoyyibatus@ub.ac.id, yenipujirahayu2@gmail.com
}

Dalam pelaksanaannya, mahasiswa dituntut untuk dapat mengelola keduanya dengan baik, sehingga dapat berjalan bersama. Namun, sampai saat ini masih sering terjadi permasalahan yang menghambat keberhasilan mahasiswa dalam penyelesaian akademiknya. Salah satu faktor yang dapat menghambat keberhasilan mahasiswa mencapai prestasi akademik adalah prokrastinasi (Reza, 2015).

Hasil penelitian dari Burka dan Yuen menyatakan bahwa 90\% dari mahasiswa perguruan tinggi telah menjadi pelaku prokrastinasi dan $25 \%$ diantaranya 
adalah orang yang suka menunda-nuda kronis dan mereka pada umumnya berakhir untuk tidak menyelesaikan masa studinya di bangku perkuliahan. Hasil penelitian Solomon \& Rothblum (1986) menemukan bahwa $50 \%$ sampai $90 \%$ mahasiswa Amerika melakukan prokrastinasi. Berdasarkan hasil penelitian tersebut disimpulkan bahwa mahasiswa merupakan pelaku prokratinasi.

Secara umum prokrastinasi merupakan masalah yang sangat serius yang membawa konsekuensi bagi pelaku prokrastinasi. Menurut Burka dan Yuen (2008) konsekuensi dapat berupa perasaan frustrasi, perasaan bersalah, lemahnya performa akademis dan pekerjaan, dan hilangnya kesempatan. Sedangkan menurut Solomon dan Rothblum (1986), beberapa konsekuensi akibat kemunculan prokrastinasi adalah tugas tidak terselesaikan, terselesaikan tetapi hasilnya tidak memuaskan karena individu terburuburu dalam menyelesaikan tugas tersebut untuk mengejar batas waktu (deadline), menimbulkan kecemasan sepanjang waktu, tingkat kesalahan yang tinggi karena individu merasa tertekan dengan batas waktu yang semakin sempit, waktu yang terbuang lebih banyak dan pada pelajar dapat merusak kinerja akademik. Begitu juga temuan dari Sarirah (2017) dalam penelitiannya bahwasannya procrastinator berhubungan negatif dengan kesejahteraan psikologis. Hal ini berarti semakin seseorang melakukan prokrastinasi, maka kesejahteraan psikologisnya rendah begitu juga sebaliknya.

Studi longitudinal yang dilakukan oleh Tice dan Baumeister (1997) ditemukan bahwa prokrastinasi memang meringankan stres, akan tetapi hanya dalam periode waktu yang singkat. Prokrastinasi memang memiliki keuntungan dalam mengurangi stres akibat tuntutan tugas, akan tetapi seiring berjalannya waktu dan mendekatnya batas penyelesaian tugas ternyata tingkat stres pada pelaku prokrastinasi meningkat dan bahkan bertambah. Dampak positif dari prokrastinasi pada jangka pendek tidaklah sebanding dengan dampak negatif yang harus dibayar pada jangka panjang (Maula, 2013).

Berdasarkan tujuan melakukan prokrastinasi, Ferrari dan Olivette (1994) membagi prokrastinasi menjadi dua, yaitu functional procrastinantion (penundaan melaksanakan tugas yang dimaksudkan untuk mendapatkan informasi yang lebih lengkap dan akurat sehingga tidak merugikan pelaku prokrastinasi) dan disfunctional procrastination (penundaan mengerjakan tugas yang tidak memiliki tujuan, memiliki akibat yang jelek dan menimbulkan masalah).

Ada dua bentuk disfunctional procrastination yaitu, decisional procrastination (penundaan dalam menentukan keputusan) dan avoidance procrastination (suatu penundaan dalam perilaku tampak). Selanjutnya, dalam penelitian ini dibatasi pengertian prokrastinasi merupakan penundaan yang direncanakan dan terus-menerus dengan melakukan kegiatan lain yang tidak diperlukan dalam pengerjakan tugas, dengan jenis disfungsional procrastination yang berbentuk avoidance procrastination.

Menurut Ferrari, Johnson \& McCown (1995) avoidance procrastination adalah penundaan pada perilaku tampak dimana penundaan ini dimaksudkan sebagai strategi untuk melakukan penghindaran dari tugas yang dianggap tidak menyenangkan dan sukar untuk dikerjakan.

Mengapa seseorang bisa melakukan prokrastinasi? Salah satunya diakibatkan oleh kepribadian. Hal ini senada dengan pendapat Ferrari, Johnson dan McCown (1995) yang mengemukakan bahwa salah satu penyebab yang memengaruhi individu untuk melakukan prokrastinasi adalah faktor internal yang terdiri dari faktor yang ada dalam diri individu berupa keadaan jasmani dan keadaan psikologis. Keadaan psikologis mengarah pada sifat kepribadian yang dimiliki individu (Dewi, 2014). 
Penelitian yang dilakukan oleh Diaz-Moralez, Cohen dan Ferrari (2008) menyatakan bahwa prokrastinasi sebagai suatu kebiasaan kepribadian, dalam pengertian ini prokrastinasi tidak hanya sebuah perilaku penundaan akan tetapi prokrastinasi merupakan suatu kebiasaan yang melibatkan komponen-komponen perilaku langsung maupun tidak langsung. Kepribadian sebagai faktor yang memegang peranan penting dalam perilaku sehari-hari dan merupakan suatu bagian yang tidak terpisahkan dalam lingkungan dimana individu tinggal.

Ferrari, Johnson, \& McCown (1995) memberikan kesimpulan bahwa definisi dari prokrastinasi dapat dipandang dari berbagai batasan tertentu, salah satunya prokrastinasi sebagai suatu trait kepribadian. Dalam pengertian ini prokrastinasi merupakan suatu trait yang melibatkan komponen-komponen perilaku maupun struktur mental lain yang saling terkait yang diketahui langsung maupun tidak langsung.

Menurut Pervin, Cervone dan Jhon (2005), kepribadian adalah ciri-ciri individu yang merupakan suatu pola yang cenderung tetaptentang perasaan, pikiran dan perilaku. Terdapat beberapa pendekatan yang dicetuskan oleh para ahli guna mengetahui kepribadian. Salah satu pendekatan yang bisa digunakan adalah teori trait. Teori trait adalah sebuah model yang dimaksudkan untuk mengidentifikasi trait-trait dasar yang dibutuhkan dalam memberikan gambaran tentang suatu kepribadian (Mastuti, 2005).

Kepribadan memiliki struktur yang berbeda satu dengan yang lain. Tidak serta merta dua orang yang diidentifikasi memiliki kepribadian yang sama benarbenar sama karena adanya perbedaan respon emosi. Emosi dapat dimanfaatkan untuk mengatasi berbagai masalah dan mengidentifikasi berbagai peluang dengan cara yang dinamis melalui berbagai jaringan respon (Damopolii \& T, 2017). Kepribadian merupakan satu bentuk trait yang relatif permanen atau karakteristik yang mengukur konsistensi perilaku seseorang. Lebih spesifiknya, kepribadian terdiri dari trait atau watak yang memicu perbedaan tingkah laku individu, konsistensi tingkah laku sepanjang waktu dan konsistensi tingkah laku dalam berbagai situasi (Feist \& Feist, 2010).

Pada penelitian ini, teori kepribadian yang digunakan adalah big five personality. Big five merupakan pengklasifikasian kepribadian yang disusun berdasarkan pendekatan lexical terhadap trait, yaitu pengklasifikasian beberapa kata atau bahasa yang digunakan dalam keseharian guna memberikan gambaran tentang ciri-ciri individu yang membedakannya dengan individu lain. Pemberian nama big five ini bukan berarti bahwa kepribadian itu hanya ada lima akan tetapi mengategorikan dari ribuan ciri ke dalam lima himpunan besar yang berikutnya disebut dimensi kepribadian, yaitu: (1) neuroticism, (2) extraversion, (3) openness to new experience, (4) agreeableness, dan (5) conscientiousness (Ramdhani, 2012). Selanjutnya, penelitian ini ingin mengkaji hubungan antara kepribadian dengan avoidance procrastination pada mahasiswa.

\section{Big Five Personality}

Menurut Larsen dan Buss (2014) kepribadian adalah himpunan trait psikologis dan perangkat di dalam individu yang dikelompokkan, relatif tetap yang mempengaruhi hubungan dan penyesuaian diri individu didalam lingkungan (mencangkup lingkungan intrafisik, fisik dan lingkungan sosial).

$$
\text { McCrae \& Costa (1990) }
$$

mengemukakan bahwa big five personality atau disebut juga dengan five factor model adalah sebuah kesepakatan diantara pendekatan teoritis yang mengacu padalimadimensi kepribadian manusia, yaitu: neuroticism, extraversion, opennes, agreeableness dan conscientiousness. Menurut McCrae \& Costa (1990), five factors model adalah organisasi trait 
kepribadian dan sifat-sifat pada gilirannya "dimensi perbedaan individu dalam kecenderungan untuk menunjukkan polapola konsisten dari pikiran, perasaan dan tindakan”. Kelima dimensi ini yang muncul dari penelitian faktor analisis melalui berbagai tes dan skala kepribadian.

Lima dimensi dari big five personality, yaitu:

(1) Neuroticism. Neuroticism mencangkup perasaan-perasaan yang negatif, misalnya rasa cemas, rasa sedih, mudah marah dan tegang. Jenis kepribadian ini memuat kecakapan individu untuk menahan stres (Mastuti, 2005).

(2) Extraversion. Extraversion menjelaskan tentang sifat-sifat interpersonal, yaitu apa yang dilakukan seseorang kepada orang lain. Jenis kepribadian ini menerangkan level kesenangan individu akan berhubungan (Mastuti, 2005).

(3) Opennes to New Experience. Opennes to new experience menjelaskan keluasan, kedalaman dan kerumitan dari sudut pandang batin dan pengalaman hidup. Jenis kepribadian ini mencangkup tentang minat seseorang (Mastuti, 2005).

(4) Agreeableness. Agreeableness menjelaskan tentang kualitas sifat interpersonal, yaitu apa yang dilakukan individu kepada orang lain mulai dari penuh kasih sayang hingga antagonis. Jenis kepribadian ini mengarah pada kecenderungan individu untuk tunduk kepada orang lain (Mastuti, 2005).

(5) Conscientiousness. Conscientiousness menerangkan tentang perilaku dalam mencapai tujuan dan kecakapan dalam mengontrol dorongan yang dibutuhkan dalam kehidupan nyata. Jenis kepribadian ini mengarah pada sejumlah tujuan yang menjadi pusat perhatian individu (Mastuti, 2005).

\section{Avoidance Procrastination}

\begin{tabular}{lcr}
\multicolumn{1}{c}{ Menurut } & Ferrari, & Johnson \& \\
McCown & (1995), & avoidance \\
procrastination & adalah & kecenderungan
\end{tabular}

individu untuk menunda kinerja tugas sebagai cara untuk melakukan penghindaran dari tugas yang tidak menyenangkan, kegagalan kinerja atau ancaman terhadap harga diri. Avoidance procrastination memiliki kaitan dengan tipe self presentation, keinginan untuk menyingkirkan diri dari tugas yang menantang dan impulsiveness.

Terdapat tiga faktor yang memerngaruhi avoidance procrastination, yaitu:

(1) Self-presentation yang tinggi. Menurut Ferrari (dalam Ferrari \& Olivette, 1994), avoidance procrastination berhubungan dengan self-presentation. Apabila individu memiliki self-presentation yang tinggi maka ia akan cenderung untuk memperhatikan penilaian dari orang lain dan takut apabila orang lain memberikan penilaian yang negatif tentang dirinya sehingga ia akan takut mengalami kegagalan dalam menghadapi tugas yang dianggapnya sulit.

(2) Self-confidence yang rendah. Menurut Ferrari, Johnson \& McCown (1995), individu yang mempunyai selfconfidence yang rendah akan cenderung melakukan avoidance procrastination karena ia tidak percaya akan kemampuan yang dimilikinya. Individu yang memiliki self-confidence yang rendah akan cenderung untuk melakukan penghindaraan terhadap tugas yang ia rasa sulit untuk dikerjakan. Hal ini dikarenakan ia takut apabila mengalami kegagalan dalam mengerjakan tugas.

(3) Self-esteem yang rendah. Menurut Ferrari, Johnson \& McCown (1995), individu yang mempunyai selfesteem yang rendah akan memberikan penilaian yang negatif pada dirinya, dimana ia menganggap bahwa dirinya bukanlah individu yang berharga dan akan mengalami suatu kegagalan apabila menghadapi suatu tugas yang sulit, sehingga cenderung melakukan avoidance procrastination. 


\section{METODE PENELITIAN}

Pada penelitian ini, pendekatan penelitian yang digunakan yaitu penelitian kuantitatif. Jenis penelitian korelasional.

\section{Responden Penelitian}

Penelitian ini adalah mahasiswa Strata-1 (S1). Penentuan jumlah sampel dilakukan dengan menggunakan rumus Slovin dan didapatkan hasil 400 sampel. Teknik sampling yang digunakan adalah teknik accidental sampling.

\section{Instrumen Penelitian}

Pada penelitian ini, peneliti menggunakan dua alat ukur, yaitu Big Five Inventory (BFI) oleh McCrae \& Costa (1997) yang terdiri dari 44 item dan Adult Inventory Procrastination (AIP) oleh McCown \& Johnson (1989) yang terdiri dari 15 item. Skala pengukuran menggunakan skala likert yang tersusun dari beberapa item pertanyaan yang bersifat favorable dan unfavorable.

\section{Teknik Analisis Data}

Peneliti menggunakan uji korelasi Pearson poduct moment.dalam melakukan analisis data, sehingga dari hasil analisis tersebut dapat diharapkan dapat diketahui hubungan kedua variabel dalam penelitian ini.

\section{HASIL DAN PEMBAHASAN}

Korelasi diuji dengan menggunakan analisis Pearson poduct moment. Hipotesis dapat diterima jika nilai koefisien korelasi lebih kecil dari 0,05.

Tabel 1. Hasil uji korelasi

\begin{tabular}{lllllll}
\hline & & $\mathbf{N}$ & $\mathbf{E}$ & $\mathbf{O}$ & $\mathbf{A}$ & $\mathbf{C}$ \\
\hline & $\mathbf{r}$ & 0,087 & $-0,169$ & $-0,074$ & $-0,160$ & $-0,516$ \\
& $\mathbf{r}^{2}$ & 0,008 & 0,029 & 0,005 & 0,026 & 0,266 \\
$\mathbf{P}$ & $\mathbf{p}$ & 0,081 & 0,001 & 0,138 & 0,001 & 0,000 \\
& & $\begin{array}{l}\text { Tidak } \\
\text { Ket } \\
\text { terdapat } \\
\text { hubungan }\end{array}$ & $\begin{array}{l}\text { Terdapat } \\
\text { hubungan }\end{array}$ & $\begin{array}{l}\text { Tidak } \\
\text { terdapat } \\
\text { hubungan }\end{array}$ & $\begin{array}{l}\text { Terdapat } \\
\text { hubungan }\end{array}$ & $\begin{array}{l}\text { Terdapat } \\
\text { hubungan }\end{array}$ \\
\hline Keterangan: & & & &
\end{tabular}

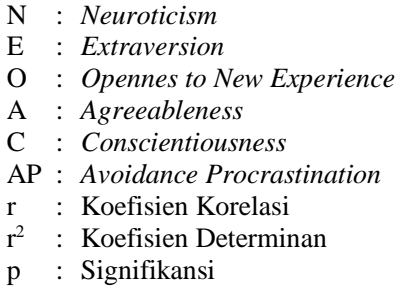

Berdasarkan hasil uji korelasi diketahui bahwa terdapat empat hubungan yang signifikan yaitu hubungan antara extraversion, agreeableness dan conscientiousness dengan avoidance procrastination $(\mathrm{p}<0,05), \quad$ sedangkan neuroticism dan openness to new experience tidak memiliki hubungan dengan avoidance procrastination ( $\mathrm{p}>0,05)$.

Hubungan yang signifikan antara kepribadian dengan avoidance procrastination $(\mathrm{p}<0,05)$ menunjukkan bahwa hipotesis diterima. Artinya, kepribadian merupakan salah satu penyebab yang mempengaruhi individu melakukan avoidance procrastination dengan persentase sebesar $12,5 \%$. Hal ini sesuai dengan pendapat Briody yang mengemukakan bahwa terdapat tiga penyebab yang memengaruhi individu untuk melakukan prokrastinasi, dimana salah satu faktornya adalah kepribadian pelaku prokrastinasi. Selain itu, pendapat dari Ferrari, Johnson, \& McCown (1995) mengemukakan bahwa salah satu penyebab yang memengaruhi individu melakukan prokrastinasi adalah faktor internal (kondisi psikologis yang mengarah pada kepribadian yang dimiliki individu) di mana pada prokrastinator seringkali mengalami rendahnya kesejahteraan psikologis (Sarirah, 2017) serta efikasi diri yang rendah (Sarirah \& Chaq, 2019). Temuan dari penelitian ini sesuai dengan hasil penelitian Watson (2001) yang menemukan bahwasannya terdapat hubungan prokrastinasi dengan big five personality.

Hubungan yang signifikan antara kepribadian extraversion dengan avoidance procrastination senada dengan hasil penelitian dari Wijaya (2014) yang menunjukkan bahwa kepribadian 
extraversion dengan prokrastinasi dengan sumbangan efektif sebesar $16.48 \%$ mempunyai hubungan sangat signifikan. Hubungan yang dimiliki extraversion dan avoidance procrastination adalah negatif, artinya semakin tinggi extraversion semakin rendah avoidance procrastination. Individu yang tergolong kepribadian extraversion dengan skor yang tinggi memiliki kecenderungan mudah bergaul, aktif, optimis, menyenangkan, kasih sayang, bersahabat, sehingga apabila ada tugas ia akan cenderung optimis bahwa dirinya bisa, apabila ada yang susah maka ia akan segera bertanya.

Hubungan yang signifikan antara agreeableness dan avoidance procrastination merupakan jenis hubungan yang negatif. Individu dengan skor tinggi pada tipe agreeableness memiliki kecenderungan memiliki hati yang lembut, baik, suka menolong, dapat dipercaya, pemaaf, mudah untuk dimanfaatkan, terus terang, kooperatif, yang dalam garis besar ciri-ciri perilaku ini bertolak belakang dengan avoidance procrastination, sehingga hasil yang menunjukkan bahwa agreeableness dan avoidance procrastination berhubungan secara negatif dapat diperkuat dan agreeableness adalah jenis kepribadian yang paling banyak melakukan prokrastinasi (Kunaeni, (2015).

Pada penelitian ini juga ditemukan bahwa dari lima jenis kepribadian dalam big five personality yang memiliki hubungan yang negatif dan cukup kuat dengan prokrastinasi jenis avoidance procrastination adalah conscientiousness. Hasil ini mempunyai kesamaan dengan hasil penelitian dari Mahardika (2017) yang menunjukkan conscientiousness dengan prokrastinasi akademik pada mahasiswa yang bekerja memiliki hubungan secara negatif. Penelitian yang dilakukan oleh Kunaeni (2015) dan Maula (2013) menyebutkan bahwa conscientiousness paling rendah melakukan prokrastinasi, artinya conscientiousness dan prokrastinasi memiliki hubungan yang negatif. Beberapa penelitian menyebutkan bahwa conscientiousness sebagai jenis dari kepribadian big five yang cukup kuat dalam memprediksi prokrastinasi, diantaranya penelitian yang dilakukan oleh Alzangana (2017) dan Schouwenburg \& Lay (1995). Apabila seseorang memiliki skor conscientiousness yang tinggi berarti avoidance procrastination tergolong rendah. Individu yang berada pada posisi ini akan cenderung untuk teratur, handal, pekerja keras, disiplin, berhati-hati, bertanggung jawab, rapi, ambisius, tekun, dimana sifat ini berlawanan dengan avoidance procrastination.

Neuroticism dan avoidance procrastination menunjukkan hasil tidak terdapat hubungan $(\mathrm{p}=0.081)$. Hasil penelitian ini menunjukkan perbedaan dengan hasil penelitian dari Swaraswati, Winarno dan Goeritno (2017) yang menunjukkan bahwa neuroticism memiliki hubungan yang positif secara signifikan dengan prokrastinasi. Selain itu, hasil penelitian dari Dewi (2014) juga menunjukkan bahwa neuroticism adalah jenis kepribadian yang paling tinggi melakukan prokrastinasi. Individu yang termasuk dalam kategori neuroticism dengan skor yang tinggi akan cenderung untuk gugup, sensitif, tegang, mudah cemas, merasa tidak nyaman, kuatir, kesedihan yang tak beralasan.

Pada hasil korelasi didapatkan hasil bahwa openness to new experience tidak ada hubungannya dengan avoidance procrastination dengan nilai signifikan sebesar 0,138. Penelitian ini menunjukkan hasil tidak sama dengan hasil penelitian dari Utaminingsih dan Setyabudi (2012) yang menunjukkan bahwa pelaku prokrastinasi yang tinggi tergolong pada jenis kepribadian openness to new experience. Individu yang tergolong openness to new experience dengan skor yang tinggi cenderung untuk memiliki rasa penasaran yang tinggi, ketertarikan luas, menyenangkan, kreatif, imajinatif, artistik, tidak ketinggalan jaman. 


\section{SIMPULAN DAN SARAN}

Berdasarkan hasil penelitian mengenai kepribadian dengan avoidance procrastination pada mahasiswa, ditarik kesimpulan bahwa:

1. Tidak terdapat hubungan antara neuroticism dengan avoidance procrastination pada mahasiswa.

2. Terdapat hubungan yang negatif antara extraversion dengan avoidance procrastination pada mahasiswa.

3. Tidak terdapat hubungan antara openness to new experience dengan avoidance procrastination pada mahasiswa.

4. Terdapat hubungan yang negatif antara agreeableness dengan avoidance procrastination pada mahasiswa.

5. Terdapat hubungan yang negatif antara conscientiousness dengan avoidance procrastination

Bagi peneliti selanjutnya disarankan untuk menggunakan variabel bebas lainnya yang memiliki hubungan dengan prokrastinasi karena masih terdapat faktor lain yang mempengaruhi prokrastinasi akademik, seperti tidak yakin diri, toleransi frustasi yang rendah, menuntut kesempurnaan, perbedaan jenis kelamin, pandangan fatalistik (putus asa berlebihan). Selain itu, juga disarankan memperhatikan demografi subjek agar hasil yang diperoleh dapat mempresentasikan hasil yang lebih spesifik, misalkan menggunakan jenis sampling kuota agar subjek dalam kategori sains dan sosial dalam proporsi yang sama.

\section{DAFTAR PUSTAKA}

Alzangana, K. (2017). Academic procrastination among international graduate students: The role of personality traits, the big-five personality trait taxonomy. Journal of Arts, Science \& Commerce, 3(1), 1-9.

Burka, J. B., \& Yuen, L. M. (2008). Procrastination: Why you do it, What to do about it now. Cambridge: Life Long.

Damopolii, M., \& T, M. Y. (2017). Analisis prokrastinasi akademik pembimbingan ilmiah: Studi kasus pada pascasarjana UIN Alauddin Makassar. Laporan Penelitian. Fakultas Tarbiyah dan Keguruan Universitas Islam Negeri Alauddin Makassar.

Dewi, I. K. (2014). Perbedaan tingkat prokrastinasi ditinjau dari tipe kepribadian the big five personality pada mahasiswa. Skripsi. Medan: Fakultas Psikologi Universitas Medan Area.

Feist, J., \& Feist, G. J. (2010). Theories of personality. Jakarta: Salemba Humanika.

Ferrari, J. R. (1992). Psychometric validation of two procrastination inventories for adults: Arousal and avoidance measures. Journal of Psychopathology and Behavioral Assessment , 14(2), 97-110.

Ferrari, J. R., \& Olivette, M. J. (1994). Parental authority and the development of female dysfunctional procrastination. Journal of Research in Personality, 28, 87-100.

Ferrari, J., Johnson, J., \& McCown, W. (1995). Procrastination and task avoidance: Theory, research and treatment. New York: Plenium Press.

Kunaeni, D. S. (2015). Hubungan antara kepribadian big five dengan prokrastinasi akademik pada mahasiswa kelas karyawan Fakultas Psikologi Universitas x. Skripsi. Fakultas Psikologi Universitas Mercu Buana.

Larsen, R. J., \& Buss, D. M. (2014). Personality psyhology: Domains of knowledge of human nature ( $5^{\text {th }} \mathrm{ed}$.). NY: McGraw Hill Education. 
Mahardika, A. P. (2017). Hubungan conscientiousness dengan prokrastinasi akademik pada mahasiswa yang bekerja. Skripsi. Malang: Program Studi Psikologi Fakultas Ilmu Sosial dan Ilmu Politik Universitas Brawijaya.

Mastuti, E. (2005). Analisis faktor alat ukur kepribadian big five (Adaptasi dari IPIP) pada mahasiswa suku Jawa. INSAN , 7(3), 264-276.

Maula, A. (2013). Hubungan karakteristik kepribadian conscientiousness dengan kecenderungan prokrastinasi akademik pada mahasiswa Fakultas Dakwah IAIN Surabaya. Skripsi. Surabaya: Program Studi Psikologi Fakultas Dakwah Institut Agama Islam Negeri Sunan Ampel.

Pervin, L., Cervone.D, \& Jhon, O. (2005). Personality theory and research. NY: John Wiley \& Sons.

Ramdhani, N. (2012). Adaptasi bahasa dan budaya inventori big five. Jurnal Psikologi, 39(2), 189-207.

Reza, I. F. (2015). Hubungan antara motivasi akademik dengan prokrastinasi akademik pada mahasiswa. Humanitas, 12(1), 39-44.

Rothblum, E. D., Solomon, L. J., \& Murakami, J. (1986). Affective, cognitive, and behavioral differences between high and low procrastinators. Journal of Counseling Psychology, 33(4), 387394.

Sarirah, T. (2017). Apakah procrastinator sejahtera psikologisnya? Studi pada dosen di Universitas $\mathrm{X}$ Malang. INSAN Jurnal Psikologi dan Kesehatan Mental, 1(2), 134-140.

Sarirah, T., \& Chaq, S.A. (2019). Academic self-efficacy as a predictor toward decisional procrastination among college students preparing a thesis in Indonesia. Journal of Advanced Research in Social Sciences and Humanities, 4(1), 23-28
Schouwenburg, H. C., \& Lay, C. H. (1995). Trait procrastination and the big-five factors of personality. Person Individual Differences, 18(4), 481490.

Siswoyo. (2007). Ilmu pendidikan. Yogyakarta: UNY Press.

Swaraswati, Y., Winarno, A. R., \& Goeritno, H. (2017). Academic procrastination of undergraduate students: The role of academic selfefficacy and the big five personality traits. Advances in Social Science, Education and Humanities Research, 118, 735-740.

Tice, D. M., \& Baumister, R. F. (1997). Longitudinal study of procrastination, performance, stress and health: The costs and benefits of dawding. Psychological Science, 8(6), 454-458.

Utaminingsih, S., \& Setyabudi, I. (2012). Tipe kepribadian dan prokrastinasi akademik pada siswa SMA "X" Tangerang. Jurnal Psikologi, 10(1), 48-57.

Watson, D.C. (2001). Procrastination and the five-factor model: A facet level analysis. Personality and Individual Differences. 30(1), 149-158.

Wijaya, T. A. (2014). Prokrastinasi akademik pada mahasiswa ditinjau dari kepribadian ekstraversi. Skripsi. Semarang: Fakultas Psikologi Universitas Katolik Soegijapranata. 